\title{
Migration and reproduction in an urbanizing context. Family life courses in 19th century Antwerp and Geneva \\ RETO SCHUMACHER ${ }^{1}$ \\ KOEN MATTHIJS ${ }^{2}$ \\ SARAH MOREELS ${ }^{2}$
}

\begin{abstract}
Résumé
Dans cette contribution, nous étudions les parcours de vie familiale de femmes natives et immigrées à Anvers et à Genève au 19ème siècle, deux contextes caractérisés par l'immigration, une forte croissance démographique et un rythme d'urbanisation soutenu. Exploitant la base de données COR pour Anvers et une reconstitution des familles pour Genève, nous analysons des parcours familiaux individuels dans une perspective séquentielle. Pour ce faire, nous considérons quatre états distincts: la phase entre le début de l'âge reproductif et le mariage (1), I'intervalle proto-génésique (2), la phase reproductive en tant que telle (3) et la phase de famille achevée (4). Dans le cas anversois, notre analyse montre une opposition entre les immigrées locales dont les parcours étaient caractérisés par une longue période reproductive et les immigrées de longue distance dont la phase de famille achevée était plus longue. Dans le cas genevois, les natives se caractérisaient par un bas âge au mariage, ce qui explique pourquoi leur phase de famille achevée était particulièrement longue.
\end{abstract}

\section{Mots clés}

Parcours de vie familiale, analyse des séquences, 19ème siècle, Anvers, Genève.

\section{Summary}

This paper investigates the family life course of native and immigrant women in 19th century Antwerp and Geneva, two contexts characterized by rapid population growth, urbanization and immigration. Using data from the COR-sample of Antwerp and from a family reconstitution of Geneva, we analyze individual family life courses in a sequential data perspective. We conceptualize the family life course as

\footnotetext{
1. University of Geneva.

2. University of Leuven.
} 
a sequence of 4 states: the phase between the entry into reproductive age and marriage (1), the interval between marriage and first birth (2), the period of childbearing (3) and the phase of completed family size (4). The analysis shows an opposition between local immigrants (characterized by long childbearing periods) and long-distance immigrants (longer periods of completed family size) in Antwerp. In Geneva, natives married at a much younger age than immigrants, which explains why their life course was characterized by a longer period of completed family size.

\section{Keywords}

Family life course, sequence analysis, 19th century, Antwerp, Geneva.

\section{Introduction}

The history of declining fertility in Western Europe is also a history of a changing socioeconomic and demographic landscape. Regional diversity in the pre-transitional demographic system increased when fertility started to decline in some regions, while in others the demographic transition was still to come. Migration undoubtedly contributed to this complicated European demographic landscape. Triggered by industrialization and urbanization, rural-urban migration between demographically distinct areas had an impact on local and regional patterns of fertility decline. Whereas migrants from pre-transitional regions may have slowed down the transition in an area where the decline had started early, individuals who migrated from transitional regions to places still rooted in pre-modern demography could have spread the new reproductive behavior to the local population.

While migration is one of the factors explaining the shape of the fertility transition in a macro-demographic perspective, it certainly is also an important variable in explaining the structure of individual family life courses. Migration could affect the family life course in several ways. Depending on the age at which migration occurred, on the individual motivation for migration, and also on the context in which migrants moved, it could postpone marriage, lengthen birth intervals, and influence the number of children born.

In this paper we explore the impact of migration on the structure of the family life course in 19th century Antwerp and Geneva. Our objective is to analyze how the diverging contexts of Antwerp and Geneva affected demographic differences between the local population and migrants. To do so, we compare natives and different categories of migrants of both cities in a explorative life course perspective. Rather than looking at 
fertility per se, we focus on complete family life courses that we study by means of sequential data analysis. The consideration of complete family life courses allows us a holistic view on reproductive and family behavior. By looking jointly at the different interacting components of the family life course, we aim at getting a better understanding of how migration affected individuals in their family formation process during the first demographic transition. We chose to compare Antwerp and Geneva in order to learn more about the interaction between context, migration and family formation. While both cities experienced high rates of immigration, demographic growth and urbanization throughout the 19th century, they were characterized by distinctive demographic and urban profiles. In the city of Geneva, fertility started to decline in the late 18th century, whereas in Antwerp the decline did not start before the second half of the 19th century. In Geneva immigrants originated therefore mostly from regions where the demographic transition had not yet started, while in Antwerp immigrants could originate from regions where the decline had already started as well as from pre-transitional regions. The two cities also differed in their economic orientation and in the socio-economic profile of their immigrants. Specialized in the production of luxury goods, Geneva mainly received skilled workers, whereas the port city of Antwerp mainly accommodated lower skilled and unskilled workers.

In the following sections, we first conceptualize the family life course and then describe the historical setting of our study. Next we present the data we use and shortly introduce the techniques of sequence analysis we apply. After the presentation of our results, we discuss the contribution of our study as well as the strengths and drawbacks of our life course approach.

\section{Migration and the family life course}

The life course concept has emerged from the confluence of different disciplines and approaches and relates social change to social structure and individual agency. It has become an important paradigm in the social sciences in general (Giele, Elder, 1998) and in demography in particular (Billari, 2003). The life course can be understood as a sequence of states, of transitions and of events which shape individual life trajectories. According to various authors, several organizing principles characterize the life course. Following Giele and Elder (1998), the life course can be seen as a process marked by its location in time and space, by its 
interaction with the life trajectories of significant others (linked lives), by human agency and by the timing of lives. Blossfeld and Huinink (2001) in turn have defined the life course as a multilevel, auto-referential and multi-dimensional process. Both conceptualizations consider the life course as a trajectory shaped by the individual who acts depending on current and previous experiences and resources, by historically formed social institutions, by the individual's ties within personal networks, and by the interactions between the life course's different domains, or to use an expression due to Willekens (1991), by the «interdependence between parallel careers».

Following this life course concept, the family life course can be conceptualized as the timing and sequencing of events relating to reproduction, such as marriage and first and consecutive births. Generally speaking, we can distinguish four different subsequences in the family life course. The first subsequence represents the phase between the beginning of the potentially reproductive or marriageable age and entry into sexual union or marriage. The interval between marriage and first birth is the second subsequence of the family life course and is followed by the childbearing period which is marked by the rhythm of successive births. The last subsequence of the family life course is a period of potentially reproductive age during which no more births occur. During the demographic transition, the family life course undergoes substantial change. Given the high rhythm of childbearing, the third subsequence is generally long in pre-transitional contexts but clearly shortens during the process of fertility decline under the effect of the spread of parity-specific fertility control. At the same time, the last subsequence which is short before the fertility transition lengthens considerably with the diffusion of birth stopping practices. As to the first subsequence of the family life course, it is usually long in pre-transitional contexts and either remains long or shortens during the demographic transition.

Migration affects the family life course in several ways. The relationship between migration and fertility has been treated extensively in the demographic literature and has led to the formulation of four partly competing hypotheses (Kulu, 2005; Milewski, 2010). Following the socialization hypothesis, immigrants shape their reproductive behavior according to the implicit rules of their region of origin, whereas the adaptation hypothesis states that immigrants adapt their fertility behavior to the behavioral pattern predominant at the place of destination. The disruption hypothesis states that given the disruption the migration process can cause in individuals' lives, fertility is low immediately following migration. According to the selection hypothesis, finally, migrants are a 
selective group of people whose fertility preferences are in line with those at destination rather than with those predominant at origin. In the life course perspective we apply in this study, these hypotheses can be formulated in terms of the life course's organizing principles. The disruption hypothesis refers to the interdependence between parallel careers in the sense of Willekens (1991), while the socialization hypothesis and the adaptation hypothesis refer to the multi-level and autoreferential aspects of the life course (Blossfeld, Huinink, 2001).

In our empirical analysis, we expect to find disruptive effects of migration on the first subsequence of the family life course. In a variety of contexts, the age at marriage of immigrants has indeed been found higher than that of natives (Alter, 1988; Lynch, 1991; Oris, 2000; Moreels, Matthijs, 2011). Delayed marriage among newcomers has usually been explained by the disruption immigrants experience through their mobility and by their lack of social networks in the new place. The length of the first subsequence in migrants' reproductive life course certainly also depends on the age at which migration takes place and on the motivation to migrate (Oris, 2000).

We further expect to find socialization and adaptation effects of migration on the third and fourth subsequences of the family life course. Depending on the demographic contexts at origin and at destination, migration can indeed have an important impact on the length of the childbearing period, on the spacing of births within this period as well as on the length of the last stage of the reproductive life course. Given the high degree of geographic diversity in demographic behavior before and during the fall in fertility, migrants can be socialized in a highfertility setting and start their family life course in a social context marked by low fertility and stopping behavior. Or, migrants born and raised in a setting of transitional fertility move to a place where the demographic transition has not yet started and find themselves confronted with traditional behavior. Whether newcomers behave according to the implicit rules of their region of origin (socialization hypothesis) or whether they adapt to the behavior that is predominant at the place of destination (adaptation hypothesis), depends on a variety of factors. George Alter (1988) has shown for 19th century Verviers that female immigrants who arrived at their place of destination as adolescents or children had the same fertility behavior as the natives. Based on socialpsychological thinking and on the concepts of social influence and behavioral confirmation (Nauck, 2001), one can also argue that shortdistance immigrants, keeping in touch with their community of origin, may have greater difficulty in adapting to new behavior than long- 
Migration and reproduction in an urbanizing context. Family life courses in 19th century Antwerp and Geneva

distance immigrants. Similarly, immigrants whose community of origin is important in the city of destination may less interact with the local population. Their behavior is therefore more likely to remain under the influence of the normative context of their place of origin (Schumacher, 2010).

\section{The historical settings of Antwerp and Geneva}

In this paper we compare the reproductive life courses of natives and immigrants in two different historical settings. Even though the two cities share a series of commonalities, both are characterized by a specific socio-demographic profile. The city of Antwerp experienced rapid urbanization and important socio-economic transformation during the 19th century. The population increased from 55'000 inhabitants in 1800 to 273 '000 inhabitants in 1900 . The major part of this population growth was due to immigration (Moreels, Matthijs, 2011). Antwerp became an international port city in the second half of the 19th century. Much of the city's economic activity was concentrated on the port and the expansion of the harbor explains the important immigration of people, mainly men, from the province of Antwerp, from other Belgian provinces as well as from the Netherlands and Germany. The constant flux of immigrants directly affected the composition of Antwerp's population. Whereas at the beginning of the 19th century $78 \%$ of the population was born in Antwerp, only 56\% of the city's population was born in town at the end of the century (Winter, 2009). Predominantly employed as workers in the port, immigrants had in general a low socio-economic status (Veraghtert, 1986), although towards the end of the 19th century the level of education also rose among newcomers. As to the demographic context of 19th century Antwerp, it was characterized by high levels of marital fertility until the 1880's, by rapid decline in fertility between 1890 and 1920, and by a loosening Malthusian preventive check during the fertility transition (see Figure 1). Infant mortality remained at high levels throughout the period under study, and especially so between 1880 and 1910 when the infant mortality rate was constantly greater than 200\%o (Vandezande et al., 2010). 
Figure 1 The demographic context of 19th century Antwerp and Geneva: Coale's fertility indexes Ig and Im

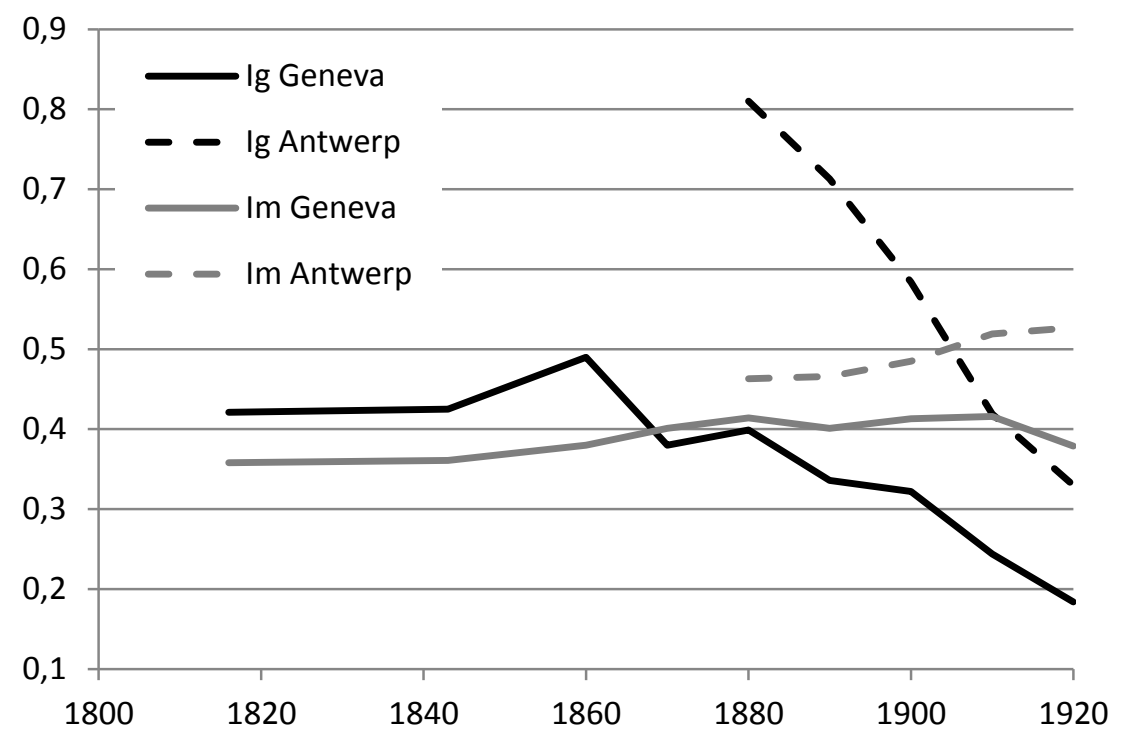

Sources: Coale and Treadway (1986) for Antwerp; Schumacher (2010) for Geneva.

Like Antwerp, the city of Geneva experienced rapid population growth and urbanization during the 19th century. The population rose from approximately $22^{\prime} 000$ in 1800 to $59^{\prime} 000$ in 1900 . The majority of this population increase was due to regional, national and international immigration. The proportion of the locally born population decreased from about two thirds at the beginning of the century to less than $30 \%$ at the turn of the 20th century (Schumacher, 2010). Throughout the 19th century, locals and natives found work in the watch-and-clock industry, in the trade sector, in domestic service and after the middle of the century in the construction sector. The immigrant population originated from French-speaking Switzerland, Savoy (belonging to the Kingdom of Sardinia until 1861) and the neighboring French departments Ain, Jura, and Doubs, but also from German-speaking Switzerland, Southern Germany and, towards the end of the century, from Northern Italy. Although their socioeconomic status was on average lower than that of the local population, only about one third of the economically active immigrants were unskilled workers. Unlike Antwerp, Geneva has evolved in a transitional demographic context throughout the 19th century. The decline of fertility started in the second half of the 18th century (Perrenoud, 1988), was then interrupted by a period of stagnation between the 1820's and the 1880 's, and continued at the end of the 19th century (Schumacher, 
2010). Access to marriage was clearly more restricted than in Antwerp, and did not increase during the decline of fertility (see Table 1). Infant mortality was clearly lower than in Antwerp, with levels oscillating between 120 and $150 \%$ during the 19 th century.

\section{Data and methods}

In this paper we use two demographic databases. For Antwerp we use the COR*-database which is an alphabetical sample of the population of 19th century Antwerp constructed by the Research Group «Family and Population Studies» of the K.U. Leuven (Matthijs, Moreels, 2010). The two main sources on which this sample has been drawn are the population registers and the vital registration records. The Belgian population registers are continuously updated longitudinal records containing demographic and socioeconomic information on individuals and households and are therefore particularly well suited for demographic research. The COR-database covers the period 1846-1920 and contains information on 30'000 individuals whose surname began with the letters $\mathrm{C}-\mathrm{O}-\mathrm{R}$ as well as their relatives. For the purpose of this study, we use information on 616 women whose family life course can be observed until the 45th birthday and who celebrated their first marriage before that age in Antwerp and who had a least one child. In this study we distinguish women born in the city of Antwerp from those born in the district of Antwerp and from those born in any other region. In the 19th century, the Antwerp district was an area encompassing a total of 62 municipalities, amongst which the city as well as suburban and rural municipalities. We therefore further distinguish between women born in rural, semi-rural or urban areas of the Antwerp district. The main objective of the COR-database being the constitution of a representative sample of the 19th century Flemish population, immigrants from Flanders may be overrepresented in our sample. In the category of other regions of birth, we do observe about $30 \%$ of non Flemish immigrants, mainly Walloons, Dutch and French, but these real long-distance immigrants are probably underrepresented in our data. We must keep this limitation in mind when interpreting the results of our analysis.

For the city of Geneva we use a family reconstitution database elaborated by Schumacher (2010). The dataset contains information on couples whose family name began with the letter B and who got married in the city of Geneva between 1800 and 1880. Their family life courses have been reconstructed until 1900 using alphabetical registers of civil birth 
and death records, immigration permits, local censuses and nominative yearbooks. Among 2'200 reconstructed birth histories, 1'045 are complete, which means that they are neither left nor right censored and can be observed until the bride's 45th birthday. As in the case of the Antwerp sample, we only chose women with a least one observed birth. In this paper we distinguish native women of the city of Geneva from women born in the canton of Geneva, from women born in the neighboring French speaking canton of Vaud, from immigrants born in Upper Savoy, from native French as well as from women born in other regions. Table 1 shows that about $54 \%$ of the selected women originated from the city and the canton of Geneva, about $14 \%$ were born respectively in upper Savoy and in the canton of Vaud and only a little more than $10 \%$ were natives of other and potentially non-French-speaking regions. As in Antwerp, female immigration had therefore a local character, although the immigration basin was clearly larger in Geneva.

In order to analyze the reproductive life courses of natives and immigrants in 19th century Antwerp and Geneva, we apply techniques of sequence analysis. Contrary to the widely used techniques of event history analysis which focus on the occurrence and timing of single or multiple events, sequence analysis represents life trajectories as sequences of states and allows thereby a holistic perspective on the life course. This technique has been frequently used in sociology and other social science disciplines (Abbott, 1995), but has only recently entered the field of population studies (Elzinga, Liefbroer, 2007; Bras et al., 2010).

In this paper we focus on female life trajectories and concentrate on a specific representation of the family life course defined as a sequence of 31 yearly states from ages 15 to 45 . We distinguish 4 different states, each corresponding to the four main phases of the family life course (see supra), namely «unmarried», «married, no children», «married, childbearing», «childbearing completed». Phase 1 represents the starting component of the family life course, phases 2 and 3 stand for the spacing component, whilst phase 4 corresponds to the stopping component. While these four states are enough to represent the family life sequences of the Geneva sample, they do not suffice to characterize the trajectories of the Antwerp sample. The Geneva dataset has been created to study marital fertility and contains very few premarital births and none among the 1'045 full life courses. On the contrary, the Antwerp database has been created in a different, more encompassing perspective and contains many illegitimate children. Among the 616 sampled women, almost $30 \%$ had their first birth before their first marriage. In order to 
Migration and reproduction in an urbanizing context. Family life courses in 19th century Antwerp and Geneva

take these premarital births into account, we further define the state «unmarried-childbearing».

In our analysis of these state sequences we start by computing the average time spent in each subsequence per region of origin of the two cities. In a next step we compute pair-wise optimal matching distances between all individual life courses (separately for the two cities) with constant substitution costs of 2 and insertion/deletion costs of 1 using the $R$ package TraMineR (Gabadinho et al., 2011). The resulting dissimilarity matrices are first used for an ANOVA-like discrepancy analysis (Studer et al., 2011) to assess the association between migratory status and family life course and to compare the level of within-group heterogeneity per region of origin. In the last step, we run a cluster analysis on the dissimilarity matrixes using the PAM algorithm (Partitioning Around Medoids) (Kaufman, Rousseeuw, 1990) to identify subtypes of family life courses in Antwerp and Geneva. Using the ASW criterion (Average Silhouette Width) we determine the quality of the partitions and the number of clusters to be retained. To analyze how the clusters are related to the women's individual profile, we run a series of logistic regression models.

\section{Results}

Table 1 shows separately for each city the distribution of years spent in the five family life course states per region of origin. In 19th century Antwerp, we can observe an opposition between long-distance immigrants and natives on the one hand, and short-distance immigrants on the other hand. Among the family life courses of natives and longdistance immigrants we find relatively long subsequences of completed family size (state 5) and on average lower numbers of achieved birth parities, whilst among the life courses of short-distance immigrants the subsequences of completed family size are clearly shorter and numbers of achieved parities higher. The longer childbearing phase contributes at least as much to the shorter stopping phase among immigrants from the Antwerp district as the higher mean age at marriage. A one-factor discrepancy analysis of the pair-wise optimal matching distances shows that the variable region of origin has a significant impact on the family life course, but that it explains only $2.8 \%$ of the total between-individual variation. It also shows that the life courses of immigrants originating from the semi-rural areas of the Antwerp district have the lowest within-group heterogeneity. 
In 19th century Geneva we can observe an opposition between natives in the broader sense and immigrants. Locals and women born in the canton of Geneva married at much lower ages than immigrants, which basically explains why their stopping phase was longer. In terms of achieved parity, there is much less variation in the Geneva sample than in the Antwerp sample. The one-factor discrepancy analysis applied to the dissimilarity between family life courses in 19th century Geneva, nevertheless confirms a significant association between region of origin and family life course, although its amount of explained individual variation is with $2.1 \%$ even lower than in Antwerp.

TABLE 1 Mean time per life course state (in years), mean age at marriage (MAM) and average parity reached by region of birth. Antwerp and Geneva

\begin{tabular}{|c|c|c|c|c|c|c|c|c|c|}
\hline \multirow{2}{*}{ Region of origin } & \multirow{2}{*}{$\mathrm{n}$} & \multirow{2}{*}{$(\%)$} & \multicolumn{5}{|c|}{ Family life course state } & \multirow{2}{*}{ MAM } & \multirow{2}{*}{$\begin{array}{c}\text { Average } \\
\text { parity }\end{array}$} \\
\hline & & & 1 & 2 & 3 & 4 & 5 & & \\
\hline City of Antwerp & 205 & 33.3 & 7.8 & 1.1 & 1.0 & 10.5 & 10.6 & 25.0 & 5.2 \\
\hline District, rural areas & 83 & 13.5 & 10.3 & 1.0 & 1.1 & 10.2 & 8.4 & 27.3 & 5.4 \\
\hline District, semi-rural areas & 103 & 16.7 & 10.9 & 0.5 & 0.8 & 11.9 & 6.9 & 27.1 & 5.7 \\
\hline District, urban areas & 88 & 14.3 & 8.0 & 0.8 & 0.5 & 12.3 & 9.4 & 25.0 & 6.5 \\
\hline Other region of birth & 137 & 22.2 & 9.7 & 1.7 & 1.0 & 8.0 & 10.6 & 27.8 & 4.4 \\
\hline Total Antwerp sample & 616 & 100.0 & 9.1 & 1.1 & 0.9 & 10.4 & 9.5 & 26.3 & 5.3 \\
\hline City of Geneva & 320 & 39.6 & 10.3 & & 1.6 & 7.8 & 11.3 & 25.3 & 3.4 \\
\hline Canton of Geneva & 117 & 14.5 & 11.5 & & 1.6 & 7.4 & 10.5 & 26.5 & 3.2 \\
\hline Canton of Vaud & 111 & 13.7 & 13.6 & & 1.4 & 6.5 & 9.4 & 28.6 & 2.8 \\
\hline Upper Savoy & 117 & 14.5 & 13.3 & & 1.6 & 7.3 & 8.9 & 28.3 & 3.4 \\
\hline France & 60 & 7.4 & 12.4 & & 2.1 & 6.8 & 9.7 & 27.4 & 3.1 \\
\hline Other region of birth & 84 & 10.4 & 13.7 & & 1.8 & 6.9 & 8.7 & 28.7 & 3.2 \\
\hline Total Geneva sample & 809 & 100.0 & 11.9 & & 1.6 & 7.3 & 10.2 & 26.9 & 3.2 \\
\hline $\begin{array}{ll}1 & \text { Unmarried. } \\
2 & \text { Unmarried, childbearing. } \\
3 & \text { Married, no children. } \\
4 & \text { Married, childbearing. } \\
5 & \text { Childbearing completed. }\end{array}$ & & & & & & & & & \\
\hline
\end{tabular}


FIGURE 2 Sorted full-sequence index plots per cluster of family life course in 19th century Antwerp

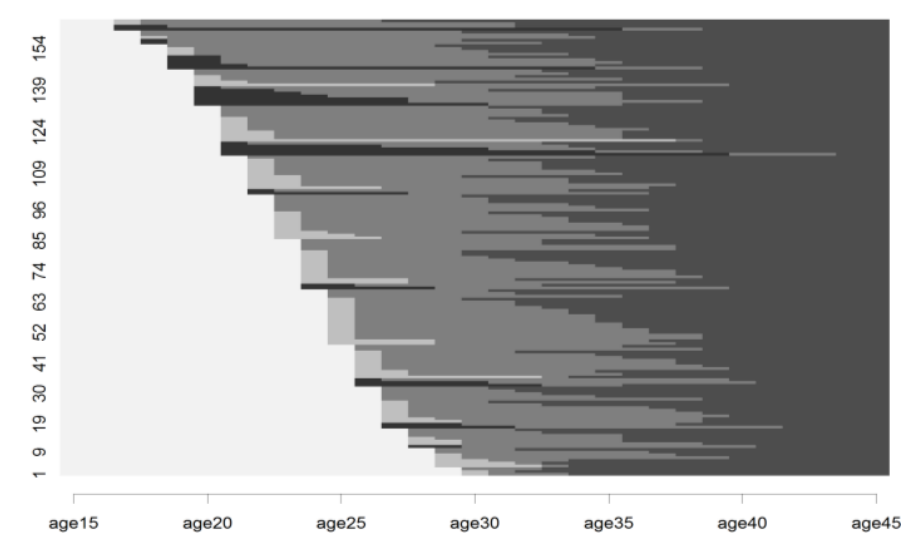

Cluster 1: Moderate stopping.

$\mathrm{n}=164$. Silhouette width $=0.23$.

Mean age at marriage $=25.1$ years.

Average parity $=4.8$.

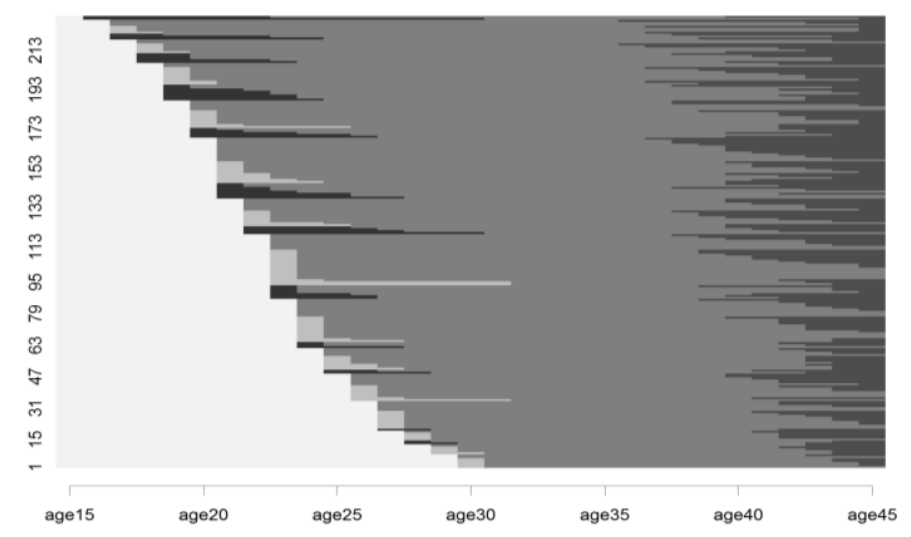

Cluster 2: no stopping.

$\mathrm{n}=230$. Silhouette width $=0.42$.

Mean age at marriage $=23.9$ years.

Average parity $=8.5$. 


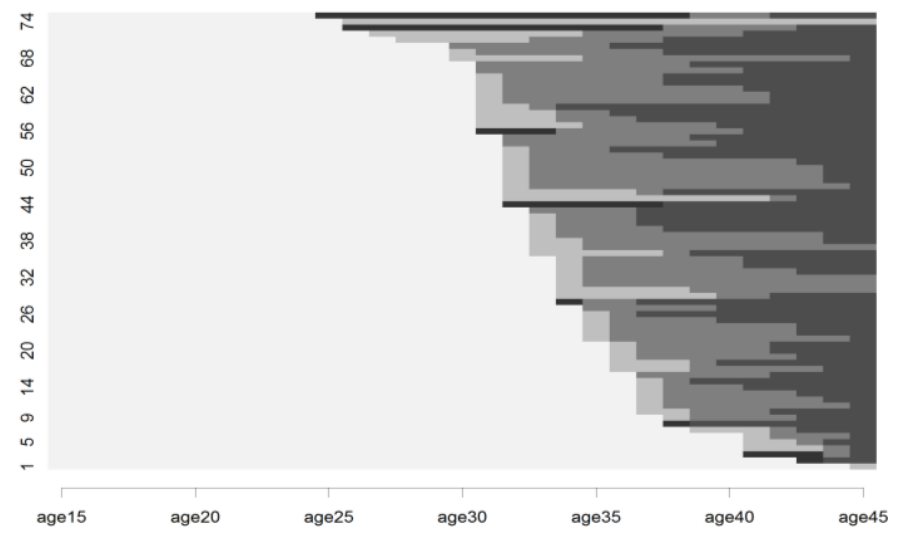

Cluster 3: late marriage.

$\mathrm{n}=75$. Silhouette width $=0.40$.

Mean age at marriage $=34.9$ years.

Average parity $=3.1$.

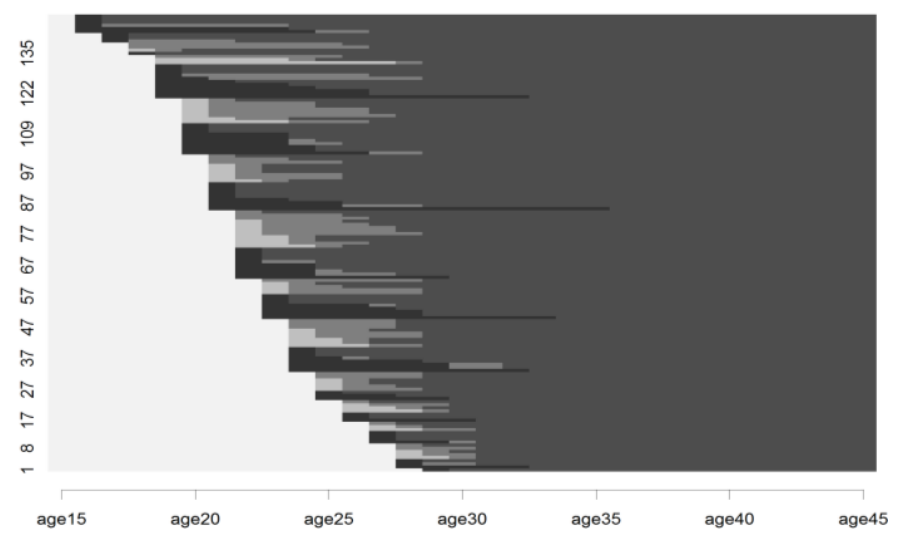

Cluster 4: illegitimacy, untypical.

$\mathrm{n}=147$. Silhouette width $=0.43$.

Mean age at marriage $=26.9$ years.

Average parity $=2.0$.

$$
\begin{aligned}
& \square \text { unmarried } \\
& \square \text { unmarried, childbearing } \\
& \square \text { married, no children } \\
& \text { married, childbearing } \\
& \text { childbearing completed }
\end{aligned}
$$

Figure 2 shows sorted full-sequence index plots of all individual family life courses of the Antwerp sample in four clusters. Index plots represent every sequence by a single line and thus allow for real longitudinal 
Migration and reproduction in an urbanizing context. Family life courses in 19th century Antwerp and Geneva

interpretation. Among the 6 tested solutions (for 3 to 8 cuts), the 4cluster solution has shown the highest average silhouette width (ASW = 0.37). Cluster 1 mostly contains sequences shaped by modern reproductive behavior: with 25.1 years the mean age at marriage is low, the childbearing subsequences are relatively short and the periods of completed family size are rather long. The median age at last birth is also below 35 years. The results of a logistic regression analysis shown in table 2 highlight that this cluster of moderate stopping is associated with later birth cohorts and with higher social status. It is also interesting to note that long-distance immigrants are clearly overrepresented in this cluster. Cluster 2 mainly contains sequences shaped by traditional fertility behavior: age at marriage is low, the childbearing subsequences are very long, whereas the periods of completed family size are very short. The median age at last birth is clearly over 40 years. The regression analysis shows that this cluster of traditional behavior is associated with early birth cohorts and with skilled and unskilled workers. Longdistance immigrants are clearly underrepresented in this cluster, which is in line with the previous result. Natives and short-distance immigrants did not differ substantially between each other with respect to their probability of belonging to this cluster. Cluster 3 embraces family life courses shaped by a high age at marriage. With almost 35 years, the mean age at first marriage is very high. Due to declining fecundability at higher ages, the waiting times between marriage and first birth are longer than in the other clusters. The late age at marriage also explains the short childbearing subsequences. Following the results of the regression analysis this cluster is mainly associated with early birth cohorts and with rural origin. Among women born in rural and semi-rural areas of the Antwerp district, as well as among long-distance immigrants, the odds of belonging to this cluster are 3 to almost 4 times higher than among natives.

Cluster 4 contains untypical family life courses, characterized by illegitimacy and very low numbers of births. According to the regression analysis, this cluster seems to be related with families living at the margins of the society. Women married to men of unknown occupation (probably men of unstable or precarious employment) are very likely to belong to this cluster. 
TABLE 2 Logistic regression models predicting the membership to different family life course clusters. Antwerp 1846-1920. Odds ratios

\begin{tabular}{|c|c|c|c|c|c|c|c|c|}
\hline & \multicolumn{2}{|c|}{$\begin{array}{c}\text { Cluster 1: } \\
\text { Moder. stopping }\end{array}$} & \multicolumn{2}{|c|}{$\begin{array}{l}\text { Cluster 2: } \\
\text { No stopping }\end{array}$} & \multicolumn{2}{|c|}{$\begin{array}{c}\text { Cluster 3: } \\
\text { Late marriage }\end{array}$} & \multicolumn{2}{|c|}{$\begin{array}{c}\text { Cluster 4: } \\
\text { Untypical/illeg. }\end{array}$} \\
\hline & OR & Sig. & OR & Sig. & OR & Sig. & OR & Sig. \\
\hline \multicolumn{9}{|l|}{ Birth cohort } \\
\hline Before 1830 & 1 & ref & 1 & ref & 1 & ref & 1 & ref \\
\hline 1830-1849 & 1.990 & 0.027 & 0.965 & 0.893 & 0.304 & 0.001 & 1.801 & 0.168 \\
\hline $1850-1864$ & 1.929 & 0.027 & 0.638 & 0.077 & 0.314 & 0.001 & 3.481 & 0.001 \\
\hline 1865 and later & 2.536 & 0.002 & 0.443 & 0.002 & 0.136 & 0.000 & 5.253 & 0.000 \\
\hline \multicolumn{9}{|l|}{ Social class } \\
\hline $\begin{array}{l}\text { Upper, white } \\
\text { collars }^{1}\end{array}$ & 1.905 & 0.018 & 0.493 & 0.014 & 1.592 & 0.261 & 0.804 & 0.512 \\
\hline Blue collars ${ }^{2}$ & 1 & ref & 1 & ref & 1 & ref & 1 & ref \\
\hline Lower $^{3}$ & 1.141 & 0.551 & 1.229 & 0.306 & 0.948 & 0.868 & 0.611 & 0.075 \\
\hline Unknown & 0.105 & 0.000 & 0.182 & 0.000 & 1.778 & 0.187 & 9.291 & 0.000 \\
\hline \multicolumn{9}{|l|}{ Region of birth } \\
\hline City of Antwerp & 1 & ref & 1 & ref & 1 & ref & 1 & ref \\
\hline $\begin{array}{l}\text { Dist. of Antwerp, } \\
\text { rural }\end{array}$ & 1.094 & 0.780 & 0.642 & 0.121 & 3.240 & 0.006 & 0.860 & 0.675 \\
\hline $\begin{array}{l}\text { Dist. of Antwerp, } \\
\text { semirural }\end{array}$ & 1.071 & 0.814 & 0.887 & 0.642 & 3.279 & 0.004 & 0.495 & 0.051 \\
\hline $\begin{array}{l}\text { Dist. of Antwerp, } \\
\text { urban }\end{array}$ & 1.050 & 0.874 & 1.333 & 0.290 & 0.987 & 0.981 & 0.615 & 0.158 \\
\hline Other region & 1.826 & 0.020 & 0.422 & 0.001 & 3.884 & 0.000 & 0.624 & 0.110 \\
\hline Constant & 0.168 & 0.000 & 1.246 & 0.358 & 0.144 & 0.000 & 0.116 & 0.000 \\
\hline Delta chi-2 & 56.4 & & 78.6 & & 51.4 & & 142.3 & \\
\hline Df & 10 & & 10 & & 10 & & 10 & \\
\hline Nagelkerke $\mathrm{R}^{2}$ & 0.128 & & 0.163 & & 0.153 & & 0.309 & \\
\hline
\end{tabular}

Figure 3 shows the sorted full-sequence index plots of three family life course clusters in the Geneva sample. In the latter the PAM cluster analysis has given the highest average silhouette width for a 3-cluster solution. Cluster 1 contains sequences marked by a late age at first marriage. Given the mean age at marriage of almost 35 years, the childbearing subsequences are rather short and the periods of completed family size not much longer than in a cluster of traditional fertility behavior. According to the regression analysis shown in table 3 , immigrants are very clearly overrepresented in this cluster. Cluster 2 mainly embraces traditional family life courses characterized by an average to low age at marriage, by relatively long childbearing subsequences and by rather short 
periods of completed family size. Although the average number of children ever born (5.2) is much lower than in the second Antwerp cluster (8.5), we can all the same assume that birth stopping was not or very little practiced among families of this cluster. The logistic regression analysis does not show any significant effects of migratory status on the probability of being part of this subgroup. However, later cohorts seem to be overrepresented in this cluster. Although this result is counterintuitive, it is in line with previous findings showing a decline in the prevalence of stopping behavior in Geneva in the second half of the $19^{\text {th }}$ century (Schumacher, 2010). Cluster 3 finally represents a typical posttransitional family life course, characterized by a low age at marriage, short childbearing periods and long subsequences of completed family size resulting from systematic parity-dependent birth control. According to the regression analysis, this stopping cluster is mainly associated with a higher social status and with nativity in Geneva.

\section{FigURE 3 Sorted full-sequence index plots per cluster of family life courses} in 19th century Geneva

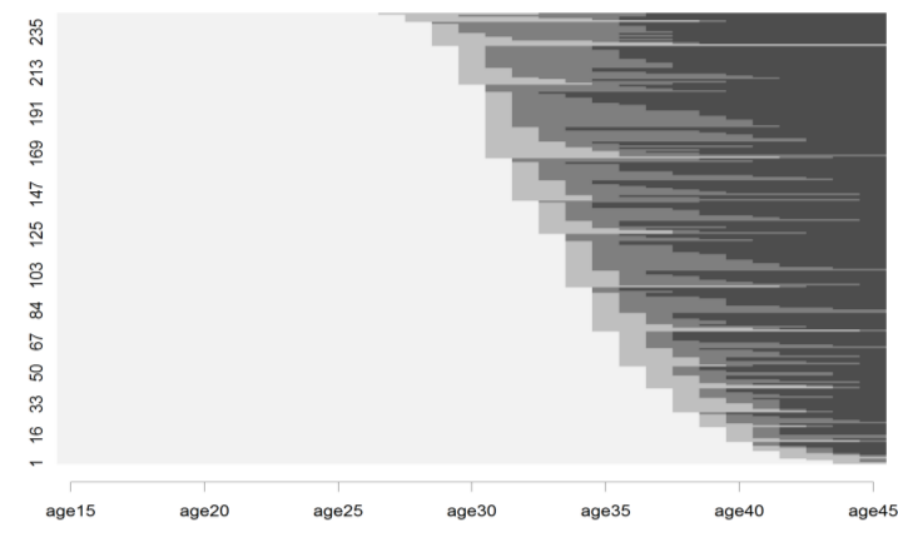

Cluster 1: late marriage.

$n=245$. Silhouette width $=0.42$.

Mean age at marriage $=33.9$ years.

Average parity $=2.2$. 


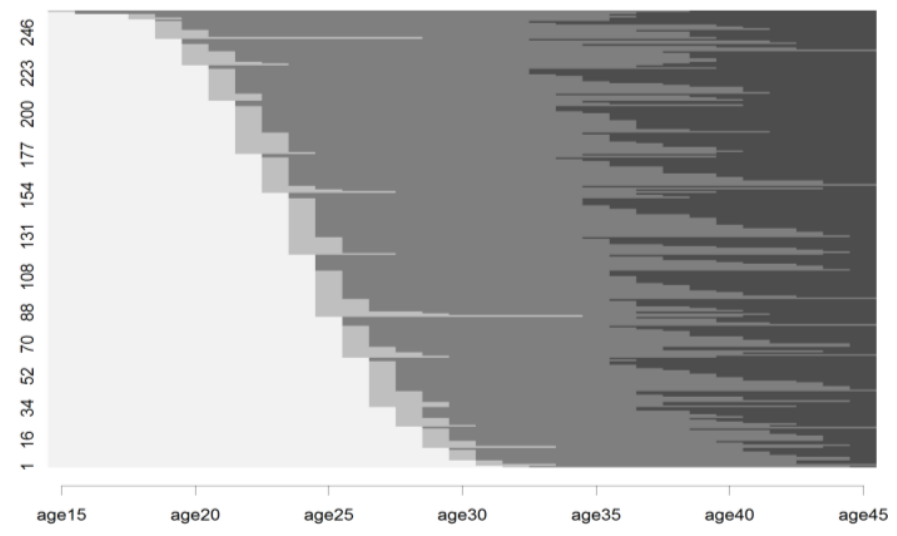

Cluster 2: no stopping.

$\mathrm{n}=258$. Silhouette width $=0.41$

Mean age at marriage $=24.2$ years

Average parity $=5.2$.

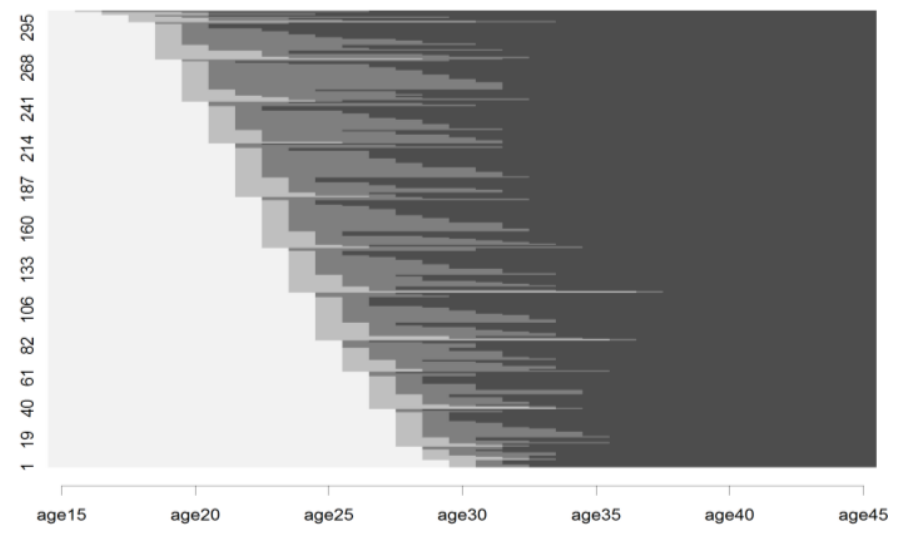

Cluster 3: stopping.

$\mathrm{n}=306$. Silhouette width $=0.44$.

Mean age at marriage $=23.5$ years.

Average parity $=2.4$.
$\square$ unmarried
- unmarried, childbearing
$\square$ married, no children
- married, childbearing
- childbearing completed 
TABLE 3 Logistic regression models predicting the membership to different family life course clusters. Geneva 1800-1900. Odds ratios

\begin{tabular}{|c|c|c|c|c|c|c|}
\hline & \multicolumn{2}{|c|}{$\begin{array}{c}\text { Cluster } 1: \\
\text { Late marriage }\end{array}$} & \multicolumn{2}{|c|}{$\begin{array}{c}\text { Cluster 2: } \\
\text { No stopping }\end{array}$} & \multicolumn{2}{|c|}{$\begin{array}{l}\text { Cluster 3: } \\
\text { Stopping }\end{array}$} \\
\hline & OR & Sig. & OR & Sig. & OR & Sig. \\
\hline \multicolumn{7}{|l|}{ Birth cohort } \\
\hline Before 1800 & 1 & ref & 1 & ref & 1 & ref \\
\hline $1800-1819$ & 0.578 & 0.020 & 1.995 & 0.003 & 0.872 & 0.537 \\
\hline 1820-1839 & 0.669 & 0.064 & 1.543 & 0.056 & 0.971 & 0.889 \\
\hline 1840 and later & 0.275 & 0.000 & 2.570 & 0.000 & 1.235 & 0.356 \\
\hline \multicolumn{7}{|l|}{ Social class } \\
\hline Upper classes ${ }^{1}$ & 0.887 & 0.637 & 0.701 & 0.128 & 1.473 & 0.072 \\
\hline White collars ${ }^{2}$ & 1.148 & 0.571 & 0.553 & 0.014 & 1.481 & 0.070 \\
\hline Blue collars ${ }^{3}$ & 1 & ref & 1 & ref & 1 & ref \\
\hline Lower classes ${ }^{4}$ & 1.484 & 0.060 & 0.926 & 0.715 & 0.716 & 0.124 \\
\hline \multicolumn{7}{|l|}{ Region of birth } \\
\hline City of Geneva & 1 & ref & 1 & ref & 1 & ref \\
\hline Canton of Geneva & 1.648 & 0.052 & 0.775 & 0.286 & 0.860 & 0.503 \\
\hline Canton of Vaud & 2.957 & 0.000 & 0.791 & 0.339 & 0.462 & 0.002 \\
\hline Upper Savoy & 2.722 & 0.000 & 0.673 & 0.118 & 0.631 & 0.062 \\
\hline France & 2.647 & 0.002 & 0.638 & 0.164 & 0.654 & 0.154 \\
\hline Other regions & 3.061 & 0.000 & 0.731 & 0.261 & 0.512 & 0.016 \\
\hline Constant & 0.370 & 0.000 & 0.389 & 0.000 & 0.749 & 0.100 \\
\hline Delta chi-2 & 62.0 & & 23.6 & & 32.4 & \\
\hline Df & 11 & & 11 & & 11 & \\
\hline Nagelkerke $\mathrm{R}^{2}$ & 0.104 & & 0.040 & & 0.053 & \\
\hline \multicolumn{7}{|c|}{$\begin{array}{l}\text { Bold coefficients are significant at the } 5 \% \text { level. } \\
{ }^{1} \text { HISCLASS } 1-3 . \\
{ }^{2} \text { HISCLASS } 4-5 . \\
{ }^{3} \text { HISCLASS } 6-7 .\end{array}$} \\
\hline
\end{tabular}

\section{Discussion and conclusion}

The aim of this paper was to compare the family life course of natives and immigrants in two urbanizing contexts of 19th century Europe. The comparison between Antwerp and Geneva was particularly promising since although sharing a series of communalities, the two cities represent two distinct socio-demographic profiles. In 19th century Geneva, immigrants who were often skilled workers mostly originated from regions where fertility was higher than at destination, whereas in Antwerp the mainly lower skilled immigrants originated from both regions with 
higher and lower fertility than at destination. To study the effect of migration on the family life course of natives and immigrants, we chose to apply a life course perspective based on techniques of sequential data analysis. In this study, we represent the family life course as a sequence of four phases. Phase 1 is a subsequence from the entry into marriageable age to first marriage, phase 2 equals the interval between first marriage and first birth, phase 3 lasts from the first to the last birth and represents the childbearing phase, whilst phase 4 stands for the period of potentially reproductive age during which no further births occur. Although our approach is genuinely explorative, we aimed at interpreting our results in terms of four effects migration can have on family formation, namely a disruptive effect, a socialization effect, an adaptation effect and a selection effect (Kulu, 2005).

As expected we found a clear disruption effect of migration on the early family life course in both cities. In Antwerp as in Geneva, migrants married and started childbearing at a substantially later age than natives and were therefore subject, all things being equal, to shorter periods of completed family size. We also found that in both cities the migrants' life course had a clearly higher propensity to be part of a family life course cluster of late marriage. In the high fertility context of 19th century Antwerp, our results highlight an opposition between short-distance and long-distance immigrants. While the former were similar to the native population and subject to a traditional family life course marked by long childbearing periods, short subsequences of completed family size and a high average number of children ever born, the latter were characterized by a transitional family life course with relatively short childbearing periods, rather long subsequences of completed family size and a clearly lower number of children ever born. Long-distance immigrants were also clearly overrepresented in a transitional life course cluster, whilst obviously underrepresented in a traditional cluster. Although only a minority of long-distance immigrant women was born in regions with lower fertility, this category of migrants seems to represent an avant-garde of modern demographic behavior in 19th century Antwerp. In the low fertility context of 19th century Geneva, the disruption effect delaying the starting phase of the family life course is the most visible impact of migration. Besides this well known effect that carries itself over to the other subsequences by shortening the remaining time span, migrants differed less from the native population and among each other than in Antwerp, although women born in the canton of Vaud and in other regions (mainly German-speaking Switzerland and Southern Germany) were substantially less likely to belong to a cluster of stopping behavior with long periods of completed family size. What has al- 
Migration and reproduction in an urbanizing context. Family life courses in 19th century Antwerp and Geneva

ready been shown in an earlier study (Schumacher, 2010) can thus be confirmed by the life course approach of this paper. On the whole, migrants from high fertility regions who got married in Geneva adapted to a large extent to the low fertility behavior of the native population, although limited socialization effects seem to be visible (see also Schumacher forthcoming) among certain categories of migrants. Unlike the port industry in 19th century Antwerp, the economic structure of 19th century Geneva may have contributed to the low fertility behavior and to the demographic adaption of migrants by employing mainly skilled workers.

The novelty of this study and what can be considered the main strength of the life course approach we applied, is the simultaneous consideration of the different phases of the family formation process. The holistic perspective on the family life course indeed highlights the «endogenous causality» (Mayer, 1987) or the «biographic opportunity costs» (Birg et al., 1991) of the family life course: late marriage automatically shortens the last subsequence of the family life course and can also affect the length of birth intervals and the number of children born through decreasing fecundability. The lower prevalence of stopping behavior (as measured by a long period of completed family size or by a low age at last birth) among certain categories of migrants as for example among women born in the canton of Vaud is also a consequence of delayed starting. The data mining approach applied in this paper is particularly promising because it allows us to reason in terms of heterogeneity and to assess the significance of the generally used social categories in multivariate demographic analysis. Still, sequential data analysis cannot replace classic demographic analysis such as rate and time-to-event modeling and should rather be seen as complimentary than as a substitute to classic methods. Also, the conceptualization of the family life course applied in this paper must be seen as a starting point for future research. The relatively crude definition of four family life states gives a general conspectus of the family life course. It shows the importance of its starting and its stopping component, but at the same time it treats the childbearing period as a black box. Future conceptualizations of the family life course may therefore also develop on the spacing component. 


\section{References}

Аввотт A. (1995), «Sequence Analysis: New Methods for Old Ideas», Annual Review of Sociology, 21 (2), pp. 93-113.

ALter G. (1988), Family and the Female Life Course. The Women of Verviers, Belgium, 1849-1880, Madison: The University of Wisconsin Press.

Billari F. (2003), "Life Course Analysis», Encyclopedia of Population, P. DemenY, G. MCNicoll (eds), 2, New York, Macmillan, pp. 588-590.

Birg H., Flöthmann E.-J., Reiter I. (1991), Biographische Theorie der demographischen Reproduktion, Frankfurt a.M., Campus Verlag.

BLossfeld H.-P., HUININK J. (2001), «Lebensverlaufsforschung als sozialwissenschaftliche Forschungsperspektive: Konzepte, Methoden, Erkenntnisse und Probleme. BIOS. Zeitschrift für Biographieforschung», Oral History und Lebensverlaufsanalysen, 14, pp. 5-31.

Bras H., Liefbroer A. C., Elzinga C. H. (2010), «Standardization of Pathways to Adulthood? An Analysis of Dutch Cohorts Born Between 1850 and 1900», Demography, 47 (4), pp. 1013-1034.

Coale A. J., Treadway R. (1986), «A Summary of the Changing Distribution of Overall Fertility, Marital Fertility, and the Proportion Married in the Provinces of Europe», The Decline of Fertility in Europe, A. J. CoAlE, S. C. WATKInS (eds), Princeton, Princeton University Press, pp. 31-79.

Elzinga C. H., LiefBroer A. C. (2007), «De-Standardization of Family-Life Trajectories of Young Adults: A Cross-National Comparison Using Sequence Analysis», European Journal of Population, 23 (3-4), pp. 225-250.

Gabadinho A., Ritschard G., Müller N. S., Studer M. (2011), «Analyzing and Visualizing State Sequences in R with TraMineR», Journal of Statistical Software, 40 (4), pp. 1-37.

Giele J. Z., Elder G. H. (1998), "Life Course Research. Development of a Field», Methods of Life Course Research: Qualitative and Quantitative Approaches, J. Z. GIELE, G. H. ElDER (eds), Thousand Oaks, Sage, pp. 5-27.

Kaufman L., Rousseeuw P. (1990), Finding Groups in Data, New York, Wiley.

KULU H. (2005), "Migration and Fertility: Competing Hypotheses Re-Examined», European Journal of Population, 21 (1), pp. 51-87.

LYNCH K. A. (1991), "The European Marriage Pattern in the Cities: Variations on a Theme by Hajnal», Journal of Family History, 16 (1), pp. 79-96.

Matthiss K., MoReels S. (2010), "The Antwerp COR*-Database: A Unique Flemish Source for Historical-Demographic Research», The History of the Family, 15 (1), pp. 109-115. 
MAYER K. U. (1987), "Lebenslaufsforschung», Methoden der Biographie- und Lebenslaufsforschung, W. VOGES (ed), Opladen, Leske and Budrich, pp. 51-73.

Milewski N. (2010), Fertility of Immigrants. A Two-Generational Approach in Germany, Heidelberg, Springer.

Moreels S., Matthus K. (2011), "Marrying in the City in Times of Rapid Urbanization», Journal of Family History, 36 (1), pp. 72-92.

NAUCK B. (2001), "Der Wert von Kindern für ihre Eltern. "Value of Children» als spezielle Handlungstheorie des generativen Verhaltens», Kölner Zeitschrift für Soziologie und Sozialpsychologie, 53 (3), pp. 407-435.

ORIS M. (2000), «The Age at Marriage of Migrants During the Industrial Revolution in the Region of Liège», The History of the Family, 5 (4), pp. 391-413.

PerRenoud A. (1988), "Espacement et arrêt dans le contrôle des naissances», Annales de Démographie Historique, pp. 59-78.

SCHUMACHER R. (2010), "Structures et comportements en transition. La reproduction démographique à Genève au 19ème siècle», Population, Famille et Société, 12, Berne, Peter Lang.

SCHUMACHER R. (forthcoming), «Demographic Socialization and Reproductive Behavior in a Transitional Context: A Macro-Micro Perspective», The History of the Family (ifirst).

Studer M., Ritschard G., Gabadinho A., MülleR N. (2011), «Discrepancy Analysis of State Sequences», Sociological Methods and Research, 40 (3), pp. 471-510.

Vandezande M., Moreels S., MatthiJs K. (2010), Explaining Death Clustering. Intergenerational Patterns in Infant Mortality. Antwerp, 1846-1905. Working Paper of the WOG Historical Demography 2010-13.

VAN LeEUWEN M., MAAS I. (2010), HISCLASS - A Historical International Social Class Scheme, Leuven, Leuven University Press.

Veraghtert K. (1986), «Part III: From Inland Port to International Port 1790-1914», Antwerp. A port for all Seasons, F. SUYKens, G. ASAERT, A. DE VOS, K. THIJS, K. VERAGHTERT (eds), Antwerpen, Ortelius Series, pp. 277-452.

Willekens F. (1991), "Understanding the Interdependence Between Parallel Careers», Female Labour Market Behaviour and Fertility. A Rational-Choice Approach, J. SieGers, J. De Jong-GIerveld, E. van ImHoff (eds), Berlin, Springer, pp. 2-31.

WinTER A. (2009), Migrants and Urban Change: Newcomers to Antwerp, 1760-1860, London, Pickering and Chatto. 